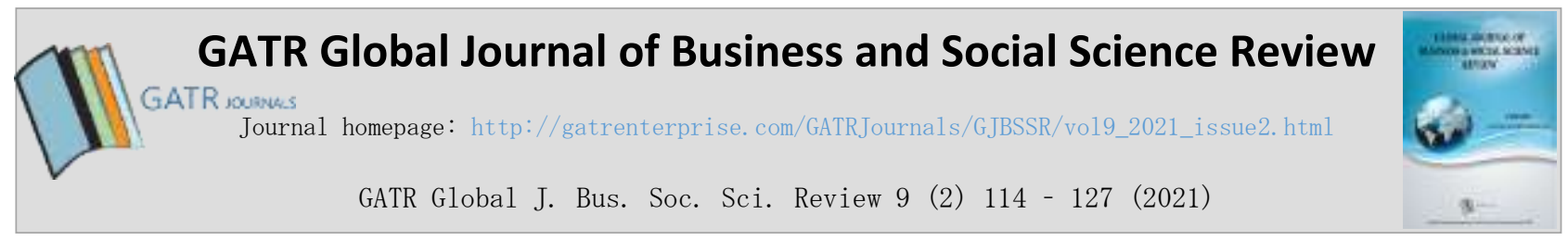

\title{
Online Business Capabilities and Online Business Performance in the Malaysian Fashion Industry
}

\author{
Teo Shao Zhen*, Siti Hasnah Hassan \\ School of Management, Universiti Sains Malaysia, Penang, Malaysia
}

\begin{abstract}
Objective - The digital economy is believed to be one of Malaysia's largest sectors as online businesses are expected to exhibit an increase of $10 \%$ in the near future. This factor eventually prompted subsequent studies on online business models. This study aims to discover the types of online business capabilities that could enhance the firm competitiveness of online business in the Malaysian fashion industry.

Methodology/Technique - A questionnaire was developed and distributed by hand to a number of Malaysian online business owners in the fashion industry. The data was analysed using SPSS version 26 and SmartPLS 3.0.

Finding - The findings indicated that digital marketing capability and CRM capability were significantly correlated to firm competitiveness, which in turn, also showed a significant and positive relationship with online business performance. Nevertheless, IT capability was an insignificant factor of firm competitiveness.

Novelty - This study concluded the importance of CRM capability and digital marketing capability for online business owners to enhance firm competitiveness. The results also implied the importance of firm competitiveness for online businesses to perform in Malaysian fashion industry.
\end{abstract}

Type of Paper: Empirical.

JEL Classification: L20, L25

Keywords: Online Business Performance, Online Business Capabilities, Digital Marketing Capability, CRM Capability, IT Capability, Firm Competitiveness, Fashion Industry

Reference to this paper should be referred to as follows: Zhen, T.S; Hassan, S.H. (2021). Online Business Capabilities and Online Business Performance in the Malaysian Fashion Industry, GATR Global J. Bus. Soc. Sci. Review, 9(2), $114-$ 127. https://doi.org/10.35609/gjbssr.2021.9.2(2)

\section{Introduction}

The emergence of internet technologies has invented a platform for entrepreneurs to embark on an entrepreneurial journey physically and virtually (Lian \& Yen, 2017). The inception of the internet has enabled entrepreneurs to engage in online business (Kiboro, 2018), which has become one of the largest economic sectors, specifically in a progressing nation like Malaysia.

\footnotetext{
* Paper Info: Revised: March 15, 2021

Accepted: June 30, 2021

* Corresponding author: Teo Shao Zhen

E-mail: shaozhenteo@yahoo.com

Affiliation: School of Management, Universiti Sains Malaysia, Malaysia
} 
As most business operations are run online, small business owners have been able to generate additional value-adding activities consequent to the rise of internet usage. Online business has been recognised as a potent way of conducting business. Kiboro (2018, p. 8) defined online business as any business whose operations entail buying and selling goods and services on a virtual platform. According to Sanchez, Correa, Buenaño, Gomez, and del Salto (2016, March) and Shao Zhen and Hassan (2019), internet-based companies are expected to exhibit an increase of $10 \%$ in the next decade, allowing business owners and consumers to overcome constraints of time and distance in online transactions, while benefiting from the global market.

In Malaysia, the online business establishments had been flourishing in recent years due to government's effort in promoting this sector. However, the online business market only contributed $6.3 \%$ of the gross value to the gross domestic product (GDP) in 2017 (Malaysian Communications And Multimedia Commission, 2018). This sector's contribution is low compared to developed countries such as China. In China, the digital economy accounted for 32.9\% of the national GDP in 2017 (Xinhua, 2018, December 23). Daniel, Domenico, and Sharma (2015) explained that online business owners usually lack capabilities, technical and business skills; thus, leading to insufficient online business performance.

The phenomenon of online business has attracted researchers and policymakers who have recognised its positive effect on economic development, especially when the Covid-19 pandemic disrupts a country's economic performance. A nation needs adequate performance in the firm-level enterprise to impact its economic development positively. Although the online business has attracted the attention of past scholars, only a few researchers have explored the types of resources and capabilities that lead to online business performance (Iyer, Srivastava, \& Srinivasan, 2019; Popa, Soto-Acosta, \& Loukis, 2016). Furthermore, past literature has emphasised the country-level evaluation of competitiveness, which measured institutions' performance, per capita income levels, productivity, and comparative costs worldwide. However, the firm level analysis of competitiveness, specifically regarding numerous potential competitive drivers among small businesses, has been relatively disregarded (Sauka, 2014).

Apart from that, the fashion industry has emerged to become a highly competitive market. Business organisations keep offering lower price and better quality to compete with competitors. According to Selvarajah (2018), fashion is a popular trend associated with the style of apparel. Words related to fashion are style, clothing, accessories, and dress. The fashion industry includes segments such as apparel, footwear, accessories, and bags. In Malaysia, fashion industry has generated large revenue that amounts to USD1039 million in 2020 (Statista, 2020). Online apparel segment also plays a vital role in fashion industry, with a USD697 million market volume in 2020 (Statista, 2020). According to Statista (2020), the fashion industry's revenue had increased from USD674 million to USD1039 million from 2017 to 2020. In 2021, this industry is foreseen to generate an income of USD1831 million in Malaysia (Statista, 2021). This signifies that fashion industry exhibits a huge potential to contribute significantly to the economic boom in Malaysia.

The nature of the online business environment prompts new research on such businesses because previous studies focusing on traditional entrepreneurship cannot be fully applied to online business. According to the DCV, a firm's capabilities have been regarded as the pivotal factors contributing to the firm's resourcefulness; hence, improving the firm competitiveness and performance. Therefore, this study aims to discover the types of online business capabilities that could enhance the firm competitiveness of online business in the Malaysian fashion industry.

\section{Literature Review}

The Dynamic Capabilities View (DCV) theory has emerged because the RBV does not explain how firms can achieve a competitive advantage and adapt to the dynamic market. The DCV aims to explain the essential role of firm capabilities in exploiting the resources to achieve a sustainable competitive advantage. This theory argues that firm capabilities are dynamic, deeply embedded in the firm, and has higher inimitability and non-substitutability of tangible resources. The DCV argued that firms achieve sustainable competitive advantage in the global market because they are equipped with the related capabilities to manage their 
internal and external competencies effectively. The ability to achieve a competitive advantage is referred to as dynamic capabilities, which can be defined as a firm's ability to integrate and reconfigure resources by learning and responding rapidly to the changing market. Dynamic capabilities allow firms to respond quickly and effectively to the changing environment through integration, transformation, renewal, and recreation of the resources and capabilities. A past study by Spiegel et al. (2016) employed the DCV, and a significant positive relationship was found between dynamic capabilities and business performance in online business. Other studies by Monteiro, Soares, and Rua (2017), Abaho, Aarakit, Ntayi, and Kisubi (2017), and Tan and Sousa (2015) found a significant relationship between the different types of firm capabilities and business performance in entrepreneurship.

The importance of measuring online business performance had been boosted considering that the internet had become an established purchasing platform for consumers. Although there are plenty of online businesses that collect data of their websites' cost and usage, i.e., web analytics, only several online business owners understand thoroughly to what extent such information can measure the performance of the sites in terms of attracting, converting, and retaining customers. Therefore, it is paramount to measure online business performance to identify what kind of improvements that online business owners are able to initiate. In this study, the definition of online business performance is adapted from Dragnic (Dragnić, 2014). The author described online business performance as the achievement of the internet-based business resulting from the activities performed as a whole, and the strategies and operational activities, as well as the management of all business segments.

Moving on, the range of complexity of online business performance measures had evolved accordingly to the emergence of well-established online trading environment. However, many business models and profit models that adopt the online purchasing platform are still highly unstable (Xiang, Chen, Mei, \& Chen, 2017). According to Sihotang, Puspokusumo, Sun, and Munandar (2020), online business performance should cover four dimensions: financial performance, customer performance, process performance, and web traffic performance. Financial performance indicates the revenue and profit earned by the online business. Customer performance concerns the achievement of new target customers and existing loyal customers. In contrast, process performance is measured through customers' satisfaction with the delivery process and conformity of goods ordered, while web traffic performance is related to the ease of access and traffic growth. The level of online business performance is pivotal because it assists online business owners to measure and evaluate the current progress of their business, as well as provides the baseline data for an overall enhancement of activities executed by the firms (Shao Zhen \& Hassan, 2019).

Firms have gained benefit from new technologies that continue to advance in terms of price reduction, better performance, and improved connectivity. New technologies have prompted the business infrastructure to conform to a new digital age (Bharadwaj, El Sawy, Pavlou, \& Venkatraman, 2013). These days, digital technologies embedded in products and services have become increasingly intricate to be disentangled from their underlying IT infrastructures. Virtual platforms enable internalisation; thus, inducing new forms of organisation capabilities, especially for online businesses that operate in the dynamic market. Online business capabilities have been conceptualised as the transformation and combination of the online business resources and organisational processes that create value to firms by developing inter-firm business competencies and improving performance (Bi, Davison, \& Smyrnios, 2017). Online business capabilities allow online firms to respond strategically to the environmental dynamics; hence, achieving a high level of performance in the industry.

Besides that, firm competitiveness relies heavily on the core competencies of a firm (Sihotang et al., 2020). Javalgi, Radulovich, Pendleton, and Scherer (2005) integrated three critical components of online business toward sustaining a competitive advantage and gaining superior performance, namely customer decision-making process, customer relationship management, and firm performance. Consumer behaviour is 
a crucial subject in online business environment because the consumers' online decisionmaking processes vary from traditional business. In the customer web-based empowerment, an online business must employ affiliation and lock-in strategies.

Moving on, the affiliation strategy develops customer trust and loyalty on the web by encouraging web site visits and establishing brand preference based on a cognitive perception of superior value. An online business with strong IT capability can enhance its website's traffic by maintaining a web interface linked to systems which manage back-end order-processing, payments, and logistics (Jiajia \& Dahai, 2010). IT capability also allows online firms to recognise and utilize the latest technologies to respond rapidly to market changes and rivals' next moves. These have helped online businesses to achieve firm competitiveness (Zhang, Zhao, \& Kumar, 2016). Besides that, the affiliation strategy also helps in attracting and increasing visitors to a firm's website. Excellent digital marketing capability helps an online business to achieve higher web traffic on its website. Subsequently, the locked-in strategy is used to compel customers from switching brands, products, or to another web site due to the "stickiness" that has been developed through CRM techniques and capability (Javalgi et al., 2005).

Digital marketing capability becomes one of the important capabilities in the digital era (Kiboro, 2018; Kigunda, 2017; Sihotang et al., 2020). This is because digital marketing helps a firm to achieve a sustainable competitive advantage (Medina, Castro, \& Guzman, 2016). Digital marketing refers to commercials that are presented online and are very essential in creating awareness toward the company with regard to products and services offered (Kigunda, 2017). Companies should integrate various marketing media to promote products and brand names on the online business platform (Sihotang et al., 2020; Wang \& Cavusoglu, 2015) by exploiting online customers' characteristics through marketing tools such as websites, banner ads, search engines, and social media, which will attract online consumers and gain their trust (Medina et al., 2016; Sihotang et al., 2020; Wang \& Cavusoglu, 2015). Digital marketing benefits businesses of all sizes by offering access to the mass market in cost-effective and measurable ways (Medina et al., 2016). In this study, digital marketing capability had been defined as a firm's ability, such as marketing planning, pricing, sales, product management, communication, distribution, and marketing implementation competencies, to market and sell its products (Wang \& Cavusoglu, 2015).

Besides that, digital marketing capability allows businesses to target the correct audience at an affordable price. Firms could maintain existing customers and develop new social networks by building brand exposure (Sharif, Salehi, \& Forghani, 2018). Digital marketing capability facilitates efficient communication and the development of internal and external relations; the increasing frequency of created opportunities has a positive marginal effect on online sales because this capability allows firms to connect with a wider range of customers despite geographical constraints (Sharif et al., 2018). Firm competitiveness enhances the networking relationships among stakeholders through the internet's connectivity, interactivity, and information availability, which will also improve communication, commitment, satisfaction, and trust among relevant parties (Mathews, Bianchi, Perks, Healy, \& Wickramasekera, 2016). Past study by Weerawardena and O'Cass (2004) found out that marketing capability positively facilitates firms in achieving a sustainable competitive advantage. Additionally, Medina et al. (2016) also concluded that the adoption of digital marketing improves the competitiveness of small enterprises in Mexico. Therefore, digital marketing capability is expected to facilitate online businesses in performing competitively in the market.

H1: There is a positive and significant relationship between digital marketing capability and firm competitiveness.

Customers can be attracted, converted, and retained by firms' marketing tools and tactics derived from Internet technologies (Wang, Cavusoglu, \& Deng, 2016). Social media applications such as Facebook, Instagram, and Twitter have now been utilised extensively by customers and business owners. Nowadays, customers utilise the social media to engage and interact with businesses for feedbacks and customer 
services. The emergence of social customers is a challenge for business owners to manage towards maintaining customer loyalty. Practitioners and researchers also have to reconsider what it means to manage customer relationship (Trainor, Andzulis, Rapp, \& Agnihotri, 2014). In this study, the CRM capability has been conceptualised as the "firm's ability to establish and maintain beneficial relationships with target customers" (Orr, Bush, \& Vorhies, 2011, p. 1075). Firms' three objectives for implementing CRM are customer attraction, conversion, and retention (Wang et al., 2016). An effective CRM will increase the shareholders' value by developing an appropriate relationship with key customers and customer segments (Foltean, Trif, \& Tuleu, 2019; Wang et al., 2016). The relationship between companies and their customers can be improved through the management of all customer-related activities, inclusive of marketing, sales, service, and support, which will identify and retain the most profitable customers, yet enhancing profitability from less lucrative customers (Tseng, 2016). Consequently, these activities add to customers' non-contractual switching costs and increase customer lifetime value for firms (Wang et al., 2016). In fact, customers are not only profitable from single transactions done with a firm, but more outstandingly, they bring an overall profit throughout the whole period of their relationship with the firm (Tseng, 2016).

Moreover, online business creates a sense of community and consumer trust by providing shared buyer experiences via customer feedback (Javalgi et al., 2005). An effective CRM strategies will increase the shareholders' value by developing an appropriate relationship with key customers and customer segments (Foltean et al., 2019; Wang et al., 2016). Providing CRM through internet technology and create an interactive web sites could offer unique values to consumers in a trustworthy environment. As a result, the firms build trust, provide positive online experiences, and create loyalty among their consumers. CRM is also capable to offer a competitive advantage of superior customer value based on customer service, problem resolution, greater satisfaction, repeat purchases, and web purchase loyalty. As is evident, CRM technology enhances customer value offerings and supports a competitive advantage by extending the business value chain, which is a characteristic of successful firms.

$\mathrm{H} 2$ : There is a positive and significant relationship between CRM capability and firm competitiveness.

IT capability enables firms to have a market niche that distinguishes their products and services in a progressively competitive business scenario. Firms with a higher IT capability have been proven to outperform their competitors because they can mobilise, deploy, and leverage IT resources with other existing resources to achieve better performance (Nwankpa \& Datta, 2017; Yeh, Lee, \& Pai, 2015). The firm can use IT resources to increase its competitive strength and encourage organisational growth through adjustment, reconfiguration, and integration (Yeh et al., 2015). IT capability has been an important organisational resource that plays a vital role in online operations (Nwankpa \& Datta, 2017). Most online operations require IT for supporting and maintaining a web interface linked to the systems of back-end orderprocessing, payments, and logistics management (Jiajia \& Dahai, 2010). In managing competitiveness, IT capability includes the recognition of technological innovations, customer preference variations, market fluctuations, competitors' responses, and rapid reconfiguration of IT resources (Zhang et al., 2016). According to Wang and Cavusoglu (Wang \& Cavusoglu, 2015), the process through which IT capability generates value for firms in the online platform is not studied explicitly, because past scholars focused more on firms' general capabilities. Therefore, it is necessary to better understand IT capability's impact on firm competitiveness and online business performance — particularly in the post-internet era.

Furthermore, past studies have revealed the positive and significant relationship between IT capability and competitive advantage (Paschke, 2009; Xie, Wang, Jiang, Zhang, \& Zhang, 2010). The importance of technological capability in the firm and national levels has been recognised (Radzi, Shamsuddin, \& Wahab, 2017). At the firm level, productivity and innovation is increased and facilitated by technological capability, whereas it enhances firm competitive advantage, productivity, and economic growth at the national level. According to Tsironis, Gotzamani, and Mastos (2017), employees equipped with IT capability have been regarded as the critical factor for online business performance because the firms could achieve a competitive 
advantage when their employees are skilled in utilising the IT resources for the purpose of steering consumers to the right products and assisting them with online payment methods. In short, internet firms possessing unique values from technology will leverage their IT competencies towards a sustainable competitive advantage, global expansion, and market dominance.

H3: There is a positive and significant relationship between IT capability and firm competitiveness.

There is no standard definition, determinants, and measurement methods for firm competitiveness due to the lack of consensus among scholars (Srivastava, Sultan, \& Chashti, 2017). Firm competitiveness is still a developing research area where studies usually adopt the definition and choose a specific measurement method or composite scale based on research objectives. Firms' core processes and assets are the important sources of firm competitiveness, where those sources could be tangible or intangible assets, which eventually offer a competitive advantage to the firms. The core processes such as human resources, operation management, and technology management processes help firms to compete more effectively than their competitors. Firms' internal factors such as strategies, structures, competencies, capabilities, and other tangible and intangible resources have also been regarded as the sources of competitiveness (Ajitabh \& Momaya, 2004).

Besides that, competitive firms can perform well in the market when they are equipped with relevant resources and capabilities. Kaur, Kumar, and Kumar (2016) identified the significant and positive relationship between firm competitiveness and business performance. The results indicated that the quality of products was the most critical aspect of facilitating sales growth. Firms should provide sufficient flexibility in manufacturing strategies and processes to remain competitive in the dynamic market. Leonidou, Fotiadis, Christodoulides, Spyropoulou, and Katsikeas (2015) in studying firms' export performance, viewed firm competitiveness from the perspective of product differentiation, and results concluded a positive relationship between competitiveness, export market performance, and financial performance. Firm competitiveness has also been studied in different dimensions such as service, price, and product advantage in the overseas markets. Results indicated that low price offering and high-quality services led to market performance (Kaleka \& Morgan, 2017). The results suggested that achieving competitive advantage would guarantee firms to gain profits.

H4: There is a positive and significant relationship between firm competitiveness and online business performance.

\section{Methodology}

The unit of analysis of the current study is the organisation. A cross-sectional data collection method was applied to test the hypotheses empirically. An online questionnaire was distributed, and a phone interview was conducted to 357 online business owners in the fashion industry, including the sectors of apparel, footwear, and accessories. A judgemental sampling method was employed in this study because there are an unknown number of online businesses that operates in fashion industry. Therefore, the samples of this study were selected based on personal judgement. The current study focused on certain criteria that online business owners must fulfil to be qualified as potential respondents:

1. Online business owners that sell fashion items through an online platform in Malaysia.

2. Online business must be established for at least three years.

3. Online business must have a landing page for transaction purposes, either an official website or ecommerce platform.

4. Online business must utilise at least one social media platform (e.g., Facebook or Instagram).

5. Online business must already be registered with the Companies Commission of Malaysia (SSM).

The data collection processes were carried out for four months from June 2020 until September 2020. A total of 103 responses were collected; only 98 responses were qualified to be used in this study. Five responses were disqualified due to incomplete information. 
Online business performance is conceptualized as the level of achievement for an internet-based business, resulting from the activities performed as a whole; it concerns business performance from the perspective of subjective measures. Eight items were adapted from Wu, Zhong, and Mei (2011) and Sihotang et al. (2020) that cover dimensions such as financial performance, customer performance, process performance, and web traffic performance. On the other hand, measures for firm competitiveness were adapted from Jiang, Bao, Xie, and Gao (2016) which consist of five items that attempted to measure the firm's abilities to defeat and outperform its main competitors with regard to the quality of products or services, the speed of recognising market changes, and the effective response to market opportunities and needs.

Besides that, online business capabilities include digital marketing capability, CRM capability and IT capability. Digital marketing capability refers to a firm's ability to communicate with customers and obtain orders online effectively. Eight items were employed from the past studies of Mathews et al. (2016) and Wang and Cavusoglu (2015). Meanwhile, five items were adapted from Kaleka and Morgan (2017) and Foltean et al. (2019) for CRM capability. The eight-item measures for IT capability were adopted from Yeh et al. (2015) and Wang and Cavusoglu (2015) to examine IT knowledge and experience in the firms.

\section{Result and Findings}

The survey was distributed to all online business owners in the fashion industry, from the sectors of apparel $(60.2 \%)$, footwear $(24.5 \%)$ and accessories (62.2\%). Most online business owners were females (73.5\%), while only $26.5 \%$ of online business owners were male. In terms of age, $37.8 \%$ of online business owners were below 25 years old, $42.9 \%$ were between 25 and 35 years old, $13.3 \%$ were between 36 and 45 years old, and $6.1 \%$ were between 46 and 55 years old. Regarding race, $56.7 \%$ of the respondents were Malays, $40.2 \%$ were Chinese, $2.1 \%$ were Indians and $1.0 \%$ were of other races. In terms of education level, most online business owners obtained a bachelor's degree $(38.9 \%)$, while only $2.1 \%$ of the respondents obtained a master's degree, $\mathrm{PhD}$, and other qualifications.

Besides that, most organisations (73.7\%) have never participated in any type of government coaching programme, while $26.3 \%$ of the organisations stated that they have participated in government coaching programmes before. In this study, most online business owners established their company as a hobby (44.9\%), and the least, established their online business to earn side income (10.2\%). About $62.2 \%$ of the online business owners funded their online business organisation using their own money. In contrast, only $1.0 \%$ of the owners funded their online business using grants.

Common method bias (CMB) has the potential to threaten the effectiveness of research. Two methods to avoid or correct $\mathrm{CMB}$ were applied in this study. Procedural remedies were applied while designing and administering the questionnaire. Survey instructions inform the participants that there are no right or wrong answers, and their answers will remain confidential. Harman's single factor test was used to determine whether CMB was present in this study. The results indicated that the first factor explains $34.88 \%$ of the data, which is less than $50 \%$ of the total variance explained. Thus, CMB did not appear to be an issue in the current research. According to Podsakoff, MacKenzie, Lee, and Podsakoff (2003), values below 50\% are the CMB threshold value. The inner variance inflation factor (VIF) was also applied to address CMB issue using SmartPLS version 3. According to Kock (2015), the cut-off point for VIF should not exceed 3.3. Otherwise, there is a possibility of multicollinearity issue. This study's VIF values ranged from 1.808 to 2.565; therefore, CMB was not an issue in this study.

Besides that, outer VIF was applied to assess multicollinearity for the survey items using SmartPLS version 3. The literature suggests that multicollinearity may not be an issue if the VIF values are lower than 10 (Mason \& Perreault Jr, 1991). In this study, the highest VIF value was 4.034; therefore, there were no serious multicollinearity issue in this study. The results described that this study's model has no issue with $\mathrm{CMB}$ and multicollinearity, suggesting that the construct's significant variation can be used for the structural model. 
The quality of the measurement model was established before examining the structural model of this study. The measurement model was examined in terms of reliability and validity. The internal composite reliability (CR), Cronbach's Alpha, individual loadings, average variance extracted (AVE), and discriminant validity were tested. Convergent validity measures the correlation level of multiple indicators within a similar structure (Hair, Sarstedt, Hopkins, \& G. Kuppelwieser, 2014). Table 1 illustrates the analysis of convergent validity and reliability in this study.

Moreover, the value of Cronbach's alpha ranged from 0.856 to 0.925 for all constructs, which are above threshold values. Regarding convergent validity, the CR values ranged from 0.897 to 0.939 , and the AVE ranged from 0.615 to 0.657 . According to Hair et al. (2014), Cronbach's alpha and CR's recommended values should be greater than 0.7 , and AVE should be greater than 0.5 to show that an instrument is valid and reliable. Hence, the results indicated that there is no issue with convergent validity and reliability of the data used in this study. Therefore, data can be used for further structural analysis.

Table 1 Convergent Validity and Reliability Analysis

\begin{tabular}{ccccc}
\hline Construct & Rho_A & CR & AVE & Cronbach's Alpha \\
\hline Online Business Performance & 0.925 & 0.935 & 0.644 & 0.920 \\
Digital Marketing Capability & 0.933 & 0.939 & 0.657 & 0.925 \\
CRM Capability & 0.861 & 0.897 & 0.636 & 0.856 \\
IT Capability & 0.918 & 0.927 & 0.615 & 0.911 \\
Firm Competitiveness & 0.881 & 0.904 & 0.654 & 0.867 \\
\hline
\end{tabular}

Discriminant validity describes the degree of empirical differences among variables. Discriminant validity analysis has been generally accepted for analysing the relationship among potential factors (Hair et al., 2014). In this study, the discriminant validity was assessed using two techniques. First, the association between the correlations of the factors and the square root of AVE was tested. Fornell-Larcker criterion measures the inter-construct correlations and the square root of AVE. The diagonal values (Table 2) indicate that the values of AVE's square root are higher than the coefficients of the correlations of all variables among each other. This shows good discriminant validity (Fornell \& Larcker, 1981b).

Table 2 Fornell-Larcker Criterion

\begin{tabular}{cccccc}
\hline & $\mathbf{1}$ & $\mathbf{2}$ & $\mathbf{3}$ & $\mathbf{4}$ & $\mathbf{5}$ \\
\hline 1. CC & $\mathbf{0 . 7 9 7}$ & & & & \\
2.DMC & 0.682 & $\mathbf{0 . 8 1 1}$ & & & \\
3. COMP & 0.692 & 0.702 & $\mathbf{0 . 8 0 9}$ & & \\
4. ITC & 0.638 & 0.581 & 0.540 & $\mathbf{0 . 7 8 4}$ & \\
5. OBP & 0.593 & 0.554 & 0.727 & 0.482 & $\mathbf{0 . 8 0 3}$ \\
\hline
\end{tabular}

Note: Values in diagonal (bolded) are the square root of the average variance extracted. $\mathrm{CC}=\mathrm{CRM}$ Capability; DMC=Digital Marketing Capability; COMP=Firm Competitiveness; ITC=IT Capability; OBP=Online Business Performance.

Second, the Heterotrait-Monotrait Ratio (HTMT) also was measured. HTMT ratio criterion was developed to specify the insensitivity of the Fornell-Larcker criterion. The value of the HTMT ratio, which is closer to 1, specifies a lack of discriminant validity in the path analysis (Fornell \& Larcker, 1981a). HTMT estimates the correlation of factors (to be more exact, the upper boundary). Two different cut-off values of 0.85 and 0.90 have been suggested for the HTMT criterion to establish discriminant validity (Henseler, Hubona, \& Ray, 2016). The HTMT.85 criterion was chosen to measure the discriminant validity of the current study. Table 3 indicates the highest value of HTMT criterion in this study was 0.801 , which is below the critical value of 0.85 . The results demonstrate that the discriminant validity of this study is adequate. 
Table 3 HTMT0.85 Criterion

\begin{tabular}{cccccc}
\hline & $\mathbf{1}$ & $\mathbf{2}$ & $\mathbf{3}$ & $\mathbf{4}$ & $\mathbf{5}$ \\
\hline 1. CC & & & & \\
2.DMC & 0.760 & & & \\
3. COMP & 0.788 & 0.763 & & \\
4. ITC & 0.710 & 0.613 & 0.591 & 0.505 \\
5. OBP & 0.658 & 0.582 & 0.801 & \\
\hline
\end{tabular}

Note: Shaded boxes are the standard reporting format for HTMT ratios. CC=CRM Capability; DMC=Digital Marketing Capability; COMP=Firm Competitiveness; ITC=IT Capability; OBP=Online Business Performance.

After examining the measurement model of this study, the hypothetical link between the construct was measured. Figure 2 represents the path coefficient and t-value of the construct. The level of significance for the path analysis was measured using the bootstrap method, with 5,000 subsamples. The $\mathrm{R}^{2}$ value expresses the descriptive power of the research model. As Hair, Ringle, and Sarstedt (2011) suggested, the recommended value for $\mathrm{R}^{2}$ of 0.25 is weak, 0.50 is moderate, and 0.75 is substantial. The $\mathrm{R}^{2}$ value of the online business performance was 0.547 , which indicates that $54.7 \%$ of the online business performance variance can be explained moderately by digital marketing capability, CRM capability, IT capability, and firm competitiveness.

Table 4 demonstrates the path coefficients' detailed values, the significance of direct effects, and bootstrapping path analysis. It shows that the T-statistics values were greater than the threshold value of 1.96, confirming the significance of the relationship among the variables (Hair Jr, Sarstedt, Ringle, \& Gudergan, 2017). The p-value were also provided to confirm significance. According to Table 5, the SEM analysis outcomes confirm that digital marketing capability was found significant and positive on firm competitiveness at $\beta=0.412, p<0.01$ (one-tailed). In contrast, CRM capability was concluded to influence firm competitiveness positively at the significant level at $\beta=0.370, \mathrm{p}<0.01$ (one-tailed). The relationship between firm competitiveness and online business performance was also found to be significant and positive at $\beta=0.592, \mathrm{p}<0.001$ (one-tailed). Therefore, H1, H2, and $\mathrm{H} 4$ were accepted. On the other hand, the relationship between IT capability and firm competitiveness was insignificant. Hence, H3 was rejected.

Table 4 Path Coefficient

\begin{tabular}{ccccc}
\hline Path (Hypotheses) & Path Coefficient & T-Values & P-Values & Decision \\
& & & & \\
\hline DMC > COMP (H1) & 0.412 & 2.570 & 0.005 & Accepted \\
CC > COMP (H2) & 0.370 & 2.888 & 0.002 & Accepted \\
ITC > COMP (H3) & 0.065 & 0.670 & 0.251 & Rejected \\
COMP > OBP (H4) & 0.592 & 4.374 & 0.000 & Accepted \\
\hline
\end{tabular}

\section{Discussions}

This study aims to deepen the understanding of the relationship between online business capabilities and firm competitiveness, and the relationship between firm competitiveness and online business performance. The survey was collected from 98 online business owners in Malaysian fashion industry, which composes of apparel, footwear, and accessories sectors. The current study revealed that digital marketing capability and CRM capability could enhance firm competitiveness; hence, firm competitiveness improves online business performance. Nevertheless, IT capability was found to be insignificant in developing firm competitiveness.

The findings deduced that CRM capability exhibited the strongest positive relationship with firm competitiveness at a significance level of $\mathrm{p}<0.01$. This is because social media platforms offer competitive 
advantage through improved customer service, better problem resolution, greater satisfaction, repeat purchase, and web purchase loyalty. According to Tseng (2016), firms that remain competitive are those who can provide customised services to the correct consumers segments. Therefore, it is very crucial for online firms to understand their customers' preferences and market needs. This result also indicates that CRM capability enables online businesses to improve customers' trust and loyalty by increasing positive buyer experiences through services based on customers' feedback (Javalgi et al., 2005). The customers' trust and loyalty allow online businesses to remain competitive and outperform their competitors.

Besides that, digital marketing capability was found to have influenced firm competitiveness positively at a significance level of $p<0.05$. This result is in line with the research conducted by Weerawardena and O'Cass (2004) and Medina et al. (2016), stating that digital marketing capability enhances firm competitiveness through maintaining and developing prevailing social networks or new customers. Efficient communication with internal and external relations can be facilitated and developed by digital marketing capability despite the geographical constraints to generate opportunities (Mathews et al., 2016; Medina et al., 2016; Sharif et al., 2018). The connectivity, interactivity, and the ease of information availability enhance the quality of network relationship; hence, improving the competitiveness of online firms (Mathews et al., 2016). The use of free digital marketing tools helps online businesses to exhibit faster and more direct communication with the clients, consumers, and the target market. Those tools also assist online business owners in reducing the number of intermediaries in the distribution channels, which later reduces the supply chain costs (Medina et al., 2016).

Furthermore, firm competitiveness was found to exhibit a positive relationship with the online business performance at a significant level of $\mathrm{p}<0.001$. This result is consistent with the past studies by Leonidou et al. (2015) and Kaur et al. (2016). This result indicated that the quality and price of products and services, strategies, and processes of the online firms are important to remain competitive in the fashion market. According to Kaur et al. (2016), competitive online firms could adapt to the changing environment by creating more advantages across the marketing mix. The capabilities and strategies of online businesses have enabled firms to establish a sustainable competitive advantage over competitors in concurrence with securing and growing their market shares to generate profits. This result showed that online businesses in the fashion industry must be competitive to obtain a high level of online business performance. On the other hand, IT capability was not an important factor in influencing firm competitiveness of online businesses in Malaysian fashion industry. Perhaps not all firms are capable of developing effective IT capability. After all, based on the complexity associated with it, only a small subset of sample is likely to own the right IT resources or capability to achieve competitiveness (Bharadwaj, 2000). Indeed, the sample of this study was mainly small online businesses. Therefore, it is rational to assume that these online businesses are not sufficiently equipped or possess correct resources to develop a strong IT capability that would improve their competitiveness. Therefore, an insignificant result was concluded between IT capability and firm competitiveness.

\section{1. Implications}

This study examined the influence of online business capabilities, such as digital marketing capability, CRM capability, and IT capability on firm competitiveness, and the effect of firm competitiveness on online business performance. An empirical analysis to test the prescribed hypotheses was based on data gathered through a survey questionnaire from online business owners in the Malaysian fashion industry.

Besides that, this study contributes to the literature of online business performance by building on previous theoretical and practical online business performance studies. The empirical results showed that the current research further extends the DCV theory. Overall, the results discovered that CRM capability and digital marketing capability affect firm competitiveness positively and significantly. The results implied the importance of firm competitiveness for online businesses to perform in this particular industry. Therefore, online business owners should focus on enhancing their CRM capability and digital marketing capability to improve their online firms' competitiveness. Meanwhile, the direct relationship between firm 
competitiveness and online business performance was also found to be positive and significant. This suggests that competitive online businesses can achieve a high level of online business performance. Online firms that strengthen their competitiveness and create a sustainable competitive advantage, will attain performance goals in their online business over the long term. Consistent with arguments from the DCV theory, firms equipped with a unique combination of resources and capabilities will have the potential to achieve a sustainable competitive advantage over competitors through the full exploitation of resources, capabilities, and value creation activities. This study contributes to the literature on this specific relationship. Given the practical contribution, this paper is of great significance to policymakers, online business owners, and educational institutions. First, policymakers can use this study's empirical results to develop programmes and policies that may assist online business owners in enhancing their competitiveness and online business performance. The government can provide training to enhance the capabilities and skills of the online business owners. The government should also disclose the market information of the industry and provide networking activities on national and international levels to assist online business owners. Second, online business owners can use this study as a guide or template to run a business successfully. They can learn about the significant factors of running an online business in the start-up phase. The importance of firm competitiveness should push it to provide new insights into current research. Online business owners should improve their online business capabilities to enhance firm competitiveness. Third, the current study could facilitate educational institutions to discover sophisticated techniques that may enhance firm competitiveness and business performance of online business owners. Educational institutions should aim to train online business owners to become more competent with the online platform. Educational institutions should also focus on online business owners' skill development of completing relevant activities and tasks.

\section{Conclusion}

The research framework of this study seeks to add to the stock of knowledge on online business capabilities and online business performance. Online business capabilities are viewed as a reflective construct, with specific reference to digital marketing capability, CRM capability, and IT capability to evaluate their independence. The current paper is expected to contribute to the extant body of literature that focuses on online business capabilities, firm competitiveness, and online business performance. Most importantly, based on the dynamic capability view theory, the research framework seeks to evaluate the role of the respective dimensions of online business capabilities in building competitiveness among online firms and their direct influence on firm performance. Thus, this research framework deepens insights into the firm competitiveness building process. It has also enhanced the understanding of online business performance in the Malaysian fashion industry and provided a wider applicability of the dynamic capability view theory. In conclusion, a thorough and continuous study on online business performance is needed to compete in this blooming sector. Providing in-depth insights about the online business capabilities, firm competitiveness and online business performance is pivotal. This sector is believed to be able to elevate Malaysia's economic development that has been influenced by Covid-19 pandemic.

\section{References}

Abaho, E. (2016). Firm capabilities, entrepreneurial competency and performance of Ugandan SMEs.

Ajitabh, A., \& Momaya, K. (2004). Competitiveness of firms: review of theory, frameworks and models. Singapore management review, 26(1), 45-61.

Bharadwaj, A., El Sawy, O. A., Pavlou, P. A., \& Venkatraman, N. (2013). Digital business strategy: toward a next generation of insights. MIS quarterly, 471-482.

Bharadwaj, A. S. (2000). A resource-based perspective on information technology capability and firm performance: an empirical investigation. MIS quarterly, 169-196. 
Bi, R., Davison, R. M., \& Smyrnios, K. X. (2017). E-business and fast growth SMEs. Small Business Economics, 48(3), 559-576.

Daniel, E. M., Domenico, M. D., \& Sharma, S. (2015). Effectuation and home-based online business entrepreneurs. International Small Business Journal, 33(8), 799-823.

Dragnić, D. (2014). Impact of internal and external factors on the performance of fast-growing small and medium businesses. Management-Journal of Contemporary Management Issues, 19(1), 119-159.

Foltean, F. S., Trif, S. M., \& Tuleu, D. L. (2019). Customer relationship management capabilities and social media technology use: Consequences on firm performance. Journal of Business Research, 104, 563-575.

Fornell, C., \& Larcker, D. F. (1981). Evaluating structural equation models with unobservable variables and measurement error. Journal of marketing research, 18(1), 39-50.

Fornell, C., \& Larcker, D. F. (1981). Structural equation models with unobservable variables and measurement error: Algebra and statistics.

Hair Jr, J. F., Sarstedt, M., Hopkins, L., \& Kuppelwieser, V. G. (2014). Partial least squares structural equation modeling (PLS-SEM): An emerging tool in business research. European business review.

Hair, J. F., Ringle, C. M., \& Sarstedt, M. (2011). PLS-SEM: Indeed, a silver bullet. Journal of Marketing theory and Practice, 19(2), 139-152.

Hair Jr, J. F., Sarstedt, M., Ringle, C. M., \& Gudergan, S. P. (2017). Advanced issues in partial least squares structural equation modeling: saGe publications.

Henseler, J., Hubona, G., \& Ray, P. A. (2016). Using PLS path modeling in new technology research: updated guidelines. Industrial management \& data systems.

Iyer, K. N., Srivastava, P., \& Srinivasan, M. (2019). Performance implications of lean in supply chains: Exploring the role of learning orientation and relational resources. International Journal of Production Economics, 216, 94-104.

P Radulovich, L., Pendleton, G., \& F Scherer, R. (2005). Sustainable competitive advantage of internet firms: A strategic framework and implications for global marketers. International Marketing Review, 22(6), 658-672.

Jiajia, M., \& Dahai, D. (2010, May). Determinants and Effect of Internet Marketing in E-Commerce: An Empirical Investigation from China. In 2010 International Conference on E-Business and E-Government (pp. 267-270). IEEE.

Jiang, X., Bao, Y., Xie, Y., \& Gao, S. (2016). Partner trustworthiness, knowledge flow in strategic alliances, and firm competitiveness: A contingency perspective. Journal of business research, 69(2), 804-814.

Kaleka, A., \& Morgan, N. A. (2017). Which competitive advantage (s)? Competitive advantage-market performance relationships in international markets. Journal of International Marketing, 25(4), 25-49.

Kaur, S. P., Kumar, J., \& Kumar, R. (2016). Impact of competitiveness on business performance: a case study of manufacturing SMEs in Northern India. International Journal of Indian Culture and Business Management, 13(2), 205225.

Kiboro, S. W. (2018). Factors Influencing Performance of Online Businesses In Kenya: A Case Of Businesses In Nairobi County (Doctoral dissertation, United States International University-Africa).

Kigunda, E. N. (2017). Effect of Digital Marketing on Competitiveness of Automobile Companies in Kenya (Doctoral dissertation, United States International University-Africa).

Kock, N. (2015). Common method bias in PLS-SEM: A full collinearity assessment approach. International Journal of e-Collaboration (ijec), 11(4), 1-10.

Leonidou, L. C., Fotiadis, T. A., Christodoulides, P., Spyropoulou, S., \& Katsikeas, C. S. (2015). Environmentally friendly export business strategy: Its determinants and effects on competitive advantage and performance. International Business Review, 24(5), 798-811.

Lian, J. W., \& Yen, D. C. (2017). Understanding the relationships between online entrepreneurs' personal innovativeness, risk taking, and satisfaction: Comparison of pure-play and click-and-mortar. Journal of Organizational Computing and Electronic Commerce, 27(2), 135-151.

Hock Eng, K., Choy Yee, W., \& Devi Chuah, N. Malaysian Communications and Multimedia Commision,(2013). Internet user survey 2012.

Mason, C. H., \& Perreault Jr, W. D. (1991). Collinearity, power, and interpretation of multiple regression analysis. Journal of marketing research, 28(3), 268-280.

Mathews, S., Bianchi, C., Perks, K. J., Healy, M., \& Wickramasekera, R. (2016). Internet marketing capabilities and international market growth. International business review, 25(4), 820-830.

Medina, N. M. A., Castro, P. Y. S., \& Guzman, M. G. (2016). Adopting Digital Marketing and Competitiveness: A Perspective of Enterprises in Mexico. International Journal of Arts and Entrepreneurship. Vol 5 (1) 57, 69. 
Monteiro, A. P., Soares, A. M., \& Rua, O. L. (2017). Linking intangible resources and export performance. Baltic Journal of Management.

Nwankpa, J. K., \& Datta, P. (2017). Balancing exploration and exploitation of IT resources: the influence of Digital Business Intensity on perceived organizational performance. European Journal of Information Systems, 26(5), 469-488.

Orr, L. M., Bush, V. D., \& Vorhies, D. W. (2011). Leveraging firm-level marketing capabilities with marketing employee development. Journal of Business Research, 64(10), 1074-1081.

Paschke, J. (2009). Adaptive IT capability and its impact on the competitiveness of firms: A dynamic capability perspective. PhD diss. RMIT University.

Podsakoff, P. M., MacKenzie, S. B., Lee, J. Y., \& Podsakoff, N. P. (2003). Common method biases in behavioral research: a critical review of the literature and recommended remedies. Journal of applied psychology, 88(5), 879.

Popa, S., Soto-Acosta, P., \& Loukis, E. (2016). Analyzing the complementarity of web infrastructure and eInnovation for business value generation. Program.

Radzi, N. M., Shamsuddin, A., \& Wahab, E. (2017). Enhancing the competitiveness of Malaysian SMES through technological capability: a perspective. The Social Sciences, 12(4), 719-724.

Sanchez, J., Correa, R., Buenaño, H., Gomez, H., \& del Salto, V. H. (2016, March). Internet business: Its origins, theoretical issues and its applications. In 2016 Third International Conference on eDemocracy \& eGovernment (ICEDEG) (pp. 71-74). IEEE.

Sauka, A. (2014). Measuring the competitiveness of Latvian companies. Baltic Journal of Economics, 14(1+ 2), 140158.

Selvarajah, D. D. (2018). The factor influencing brand loyalty in fashion industry among generation Y in Malaysia. International Journal of Business and Management, 13(4), 201-209.

Shao Zhen, T., \& Hassan, S. H. (2019). Conceptualization of Internet Entrepreneurship's Success Factors on Online Business Performance in Malaysia. Paper presented at the The 13th Asian Academy of Management International Conference 2019, Penang, Malaysia.

Sharif, P. S., Salehi, S., \& Forghani, H. (2018). Determining the marketing capabilities of small and medium-sized industries for the international market. National Academy of Managerial Staff of Culture and Arts Herald, (1).

Sihotang, J., Puspokusumo, R. A. A. W., Sun, Y., \& Munandar, D. (2020). Core competencies of women entrepreneur in building superior online business performance in Indonesia. Management Science Letters, 10(7), 1607-1612.

Spiegel, O., Abbassi, P., Zylka, M. P., Schlagwein, D., Fischbach, K., \& Schoder, D. (2016). Business model development, founders' social capital and the success of early-stage internet start-ups: a mixed-method study. Information Systems Journal, 26(5), 421-449.

Srivastava, S., Sultan, A., \& Chashti, N. (2017). Influence of innovation competence on firm level competitiveness: an exploratory study. Asia Pacific Journal of Innovation and Entrepreneurship.

Gage, K., \& Pasricha, A. (2020). Fashion in India.

Gage, K., \& Pasricha, A. (2021). Fashion in India.

Tan, Q., \& Sousa, C. M. (2015). Leveraging marketing capabilities into competitive advantage and export performance. International Marketing Review.

Trainor, K. J., Andzulis, J. M., Rapp, A., \& Agnihotri, R. (2014). Social media technology usage and customer relationship performance: A capabilities-based examination of social CRM. Journal of business research, 67(6), 12011208.

Tseng, S. M. (2016). Knowledge management capability, customer relationship management, and service quality. Journal of enterprise information management.

Tsironis, L. K., Gotzamani, K. D., \& Mastos, T. D. (2017). e-Business critical success factors: toward the development of an integrated success model. Business Process Management Journal.

Wang, S., \& Cavusoglu, H. (2015). Small and medium sized manufacturer performance on third party B2B electronic marketplaces: The role of enabling and IT capabilities. Decision Support Systems, 79, 184-194.

Wang, S., Cavusoglu, H., \& Deng, Z. (2016). Early mover advantage in e-commerce platforms with low entry barriers: The role of customer relationship management capabilities. Information \& Management, 53(2), 197-206.

Weerawardena, J., \& O'Cass, A. (2004). Exploring the characteristics of the market-driven firms and antecedents to sustained competitive advantage. Industrial marketing management, 33(5), 419-428.

Wu, J. N., Zhong, W. J., \& Mei, S. E. (2011). Application capability of e-business, e-business success, and organizational performance: Empirical evidence from China. Technological Forecasting and Social Change, 78(8), $1412-1425$. 
Xiang, Y., Chen, X., Mei, L., \& Chen, J. (2017, July). Influence of social networks, opportunity identification on the performance of internet entrepreneurship: The evidence of Zhejiang province in China. In 2017 Portland International Conference on Management of Engineering and Technology (PICMET) (pp. 1-8). IEEE.

Xie, W., Wang, Y., Jiang, L., Zhang, G., \& Zhang, D. (2010). Research on the Relationship between IT Capability and Competitive Advantage--Mediating Effect of Organizational Technology and Moderating Effect of Environmental Uncertainty [J]. Science of Science and Management of $S . \& T, 12$.

García-Herrero, A., \& Xu, J. (2018). How big is China's digital economy?

Yeh, C. H., Lee, G. G., \& Pai, J. C. (2015). Using a technology-organization-environment framework to investigate the factors influencing e-business information technology capabilities. Information Development, 31(5), 435-450.

Zhang, P., Zhao, K., \& Kumar, R. L. (2016). Impact of IT governance and IT capability on firm performance. Information Systems Management, 33(4), 357-373. 